\title{
Epidemiological Study on Beta-hemolytic Strepto- coccal Infections in Yamagata Prefecture
}

\author{
Satoji Sakano \\ Department of Bacteriology, Tohoku University School of \\ Medicine, Sendai
}

\begin{abstract}
SaKano, S. Epidemiological Study on Beta-hemolytic Streptococcal Infections in Yamagatx Prefecture. Tohoku J. exp. Med., 1971, 103 (2), 167-187 — Epidemiological and bacteriological survey of streptococcal infections in a rural prefecture, Yamagata, has been continued for 15 years. After the World War II, cases of acute nephritis were detected from 1955 to 1957 , and these infections yielded the isolation of group C streptococei. The outbreak of scarlet fever in 1959 was caused by types 1 and 6 of group A streptococci. Thereafter, from the outbreaks of pharyngitis and nephritis, either type 6 , or 12 , or 22 group A streptococcus was isolated as a causative agent.

One year survey made recently on the correlation of the clinical pictures with the isolated streptococcus strains revealed that the clinical manifestations of the children under 10 years old, at older school age, and of the adults were in the form of acute pharyngitis, catarrhal tonsillitis and pirulent tonsillitis, respectively. These were infections due to types 12 and 22. Variation of types of group A streptococcus in these 15 years in Yamagata Prefecture was discussed on the basis of nation-wide isolation results of streptococci beta-hemolytic streptococcal infection
\end{abstract}

It has been well known that $\beta$-hemolytic streptococci cause scarlet fever, acute glomerulonephritis, acute pharyngitis, tonsillitis, otitis media, rheumatic fever and many kinds of suppurative diseases.

Although resistant strains against penicillin have scarcely been isolated from clinical specimens so far, ${ }^{1}$ the eradication of the germ from human population has not been achieved. In spite of the fact that severe cases or malignant complications due to the streptococcal infection have remarkably been reduced, sporadic cases of angina, endemic outbreaks of acute nephritis and scarlet fever have not disappeared yet.

At present, $\beta$-hemolytic streptococci are classified into 13 or more groups according to the carbohydrate antigen, and human pathogenic group A streptococci are divided into many types according to the acid-fast $M$ protein. ${ }^{1,2} T$ antigens are also present in most strains of group $\mathrm{A}$ streptococci, and as in the case of $\mathrm{M}$ antigens, they are composed of a large number of serologically distinct proteins. Recently T-agglutination is commonly provided as useful and convenient adjunct for the determination of streptococci. ${ }^{2,3}$

Such abundance of immunological types of the bacteria may partially explain

Received for publication, September 21, 1970. 
why we cannot succeed in elimination of the streptococcal infections. Although, the application of effective drugs such as penicillin and macrolides can improve some acute clinical manifestations, the subsequent inapparent infection or the carrier state may easily occur after an incomplete treatment. ${ }^{4}$ On the other hand, when a good-designed chemotherapy is carried out, it will be able to eradicate the germ from the throat of a patient. However, such a patient probably loses a chance to acquire the immunity against the germ. ${ }^{5}$

The author has made efforts for these 15 years to isolate $\beta$-hemolytic streptococci from various endemic cases in Yamagata Prefecture, determining their groups and types to know the extent of their spread.

In this paper, an attempt was made firstly to clarify the differences of groups and types of strains which had been isolated during 1955 to 1969 from the residents in various areas of Yamagata Prefecture of 1,300,000 population. Secondly, the efforts to correlate the causative agents with the patient's symptoms were made in a particular year. In the latter study, 89 cases out of 388 were demonstrated to have one type of group A streptococci. The latter part of the works indicated that the outbreaks of streptococcal infection with no signs of scarlet fever and acute nephritis existed in a rural town. Type 12 was the majority of the strains isolated.

\section{Materials and Methods}

1) Longitudinal study during 1955-1969: Whenever the outbreaks of acute nephritis and scarlet fever are reported from the public health stations locating in Yamagata Prefecture, throat swab specimens were obtained from the representative cases or the contacts without appreciable clinical signs.

2) One year survey in a hospital of a rural town: A total of 388 cases of acute pharyngitis and tonsillitis who visited the hospital were examined by the author during the period of June 1968 to June 1969.

Patients used for the study were categorized as follows:

1. Acute pharyngitis: general reddening and inflammatory swelling or edema of pharyngeal wall.

II. Catarrhal tonsillitis: strong redness and swelling of tonsils without any suppurative exudate on the surface.

III. Purulent tonsillitis: in addition to reddening and swelling of tonsils, purulent exudate was found in lacuna or follicle.

IV. Tonsillitis with serious local lesion: tonsillitis accompanying severe local lesions such as ulceration and peritonsillar or retropharyngeal abscess.

3) Specimens for isolation of $\beta$-hemolytic streptococcus: The cotton-tipped applicator was used to swab the posterior section of pharynx and tonsillar area. Patients examined were confirmed that they had not been treated with antibiotics or sulfa drugs. The swabs were dipped into the tubes containing $10 \mathrm{ml}$ of broth $\left(\mathrm{pH} \mathrm{7.2)}\right.$ and then stored at $4^{\circ} \mathrm{C}$ usually within a week.

4) Isolation and identification: An aliquot of the broth was streaked on a tryptosoya agar plate containing $5 \%$ horse or rabbit blood, then incubated at $37^{\circ} \mathrm{C}$ for 24 hours. Usually 10 colonies showing $\beta$-hemolysis on every plate were subcultured separately in Todd Hewitt's broth. This subculture was stored at $-20^{\circ} \mathrm{C}$ in a freezer until typing.

Determination of group was performed as follows:

I. Bacitracin sensitivity test:

Difco Bacitracin of 5 units per $\mathrm{ml}$ was used. When an obvious inhibitory zone 
around a dise of filter paper immersed in the bacitracin solution was detected, the strain was assumed to be one of the group A streptococci.

II. Hemolysis inhibition test:

Following Kobayashi's method, when a colony showed suppressed hemolysis on the agar plate containing one per cent of glucose, this strain was assumed to be a member of the group A streptococci.

III. Precipitin test by standard grouping antisera:

According to Lancefield's method, C precipitin test was done using standard grouping antisera prepared by DIFCO or Kitasato Institute. Group A strains which satisfied the above three tests were further tested for their types.

5) Typing of group A streptococci by $T$ agglutination: One platinum loop of the newly subcultured strain in the Todd Hewitt's medium was mixed with an adequate volume of the standard serum on a slide glass. When tiny flocculous agglutination appeared within a minute, it was recorded as positive, provided that non-specific spontaneous agglutination was excluded by heating the organism in the fluid culture at $50^{\circ} \mathrm{C}$ for $15 \mathrm{~min}$ before the test. A series of standard strain given through the courtesy of Dr. Miyamoto of the Kanagawa Prefectural Institute for Public Health consisted of T-1, -2, -3, 4, -5, -6, $-8,-9,-11$, $-12,-13,-14,-18,-22,-23,-25,-27,-28,-44$, B3261 and Imp. 19.

Pathogenic bacteria other than $\beta$-hemolytic streptococci such as Staphylococcus and Str. viridans were occasionally isolated. However, the study was only conducted with the cases, from which $\beta$-hemolytic streptococei were predominantly isolated.

\section{Results}

\section{1) Chronological aspects of streptococcus isolation in Yamagata Prefecture}

Fig. 1. illustrates the geographical outline of Yamagata Prefecture which consists of 4 counties. The incidence of outbreaks of streptococcal infections from

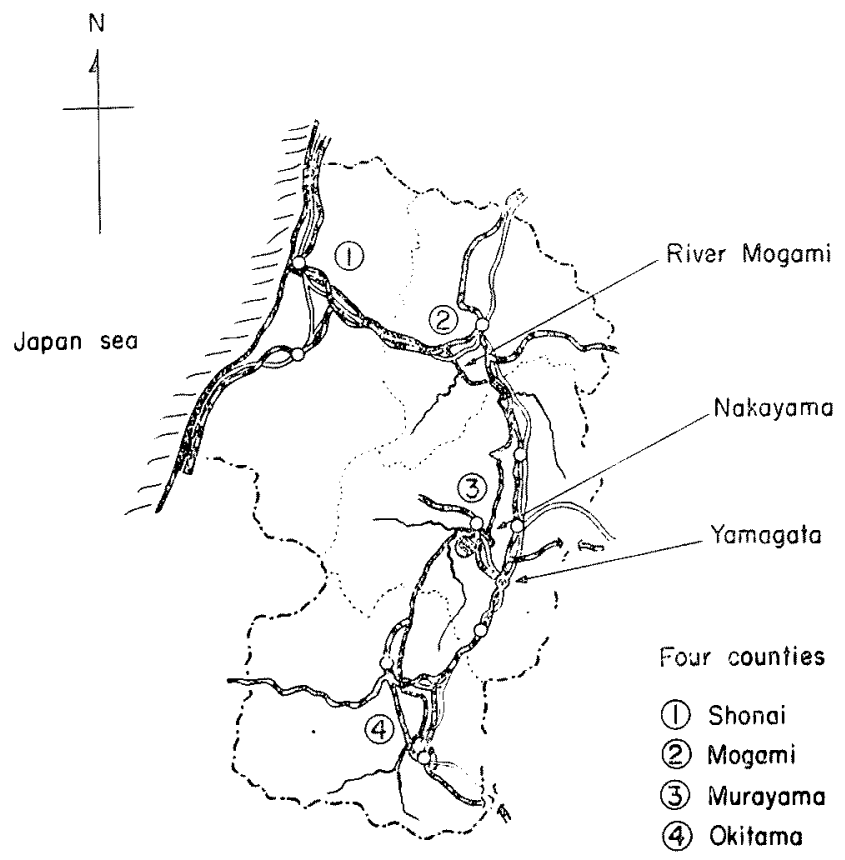

Fig. 1. Geographic feature of Yamagata Prefecture. 
TABLE 1. Outbreaks of $\beta$-hemolytic streptococcal infections

\begin{tabular}{|c|c|c|c|c|}
\hline Year & Area & $\begin{array}{c}\text { Clinical } \\
\text { diagnosis } \\
\text { (No. of cases) }\end{array}$ & Season & $\begin{array}{c}\text { Ages } \\
\text { (years) }\end{array}$ \\
\hline 1955 & Shönai & $\begin{array}{l}\text { Acute } \\
\text { nephritis } \\
(525)\end{array}$ & Summer & 3 to 14 \\
\hline 1956 & Tendō City & $\begin{array}{l}\text { Acute } \\
\text { nephritis } \\
\text { (19) }\end{array}$ & $\begin{array}{l}\text { Autumn } \\
\text { to } \\
\text { winter }\end{array}$ & $\begin{array}{l}\text { Primary } \\
\text { school }\end{array}$ \\
\hline 1957 & Shönai & $\begin{array}{l}\text { Acute } \\
\text { nephritis } \\
(109)\end{array}$ & $\begin{array}{l}\text { Summer } \\
\text { to } \\
\text { autumn }\end{array}$ & 3 to 10 \\
\hline 1959 & Shönai & $\begin{array}{l}\text { Searlet } \\
\text { fever } \\
(291)\end{array}$ & $\begin{array}{l}\text { Autumn } \\
\quad \text { to } \\
\text { early } \\
\text { winter }\end{array}$ & 0 to 25 \\
\hline $\begin{array}{l}1957 \\
1960\end{array}$ & $\begin{array}{l}\text { Murayama } \\
\text { and a } \\
\text { part of } \\
\text { Okitama }\end{array}$ & $\begin{array}{l}\text { Acute } \\
\text { nephritis } \\
(70)\end{array}$ & & \\
\hline $\begin{array}{c}1964 \\
? \\
1966\end{array}$ & $\begin{array}{l}\text { Yamagata } \\
\text { City }\end{array}$ & $\begin{array}{l}\text { Acute } \\
\text { pharyngitis } \\
\text { (102; included } \\
7 \text { with rash) }\end{array}$ & & \\
\hline 1968 & $\begin{array}{l}\text { Yamagata } \\
\text { City }\end{array}$ & $\begin{array}{l}\text { Acute } \\
\text { nephritis }\end{array}$ & $\begin{array}{l}\text { Early } \\
\text { spring }\end{array}$ & $\begin{array}{l}7 \text { to } 12 \\
\text { (primary } \\
\text { school) }\end{array}$ \\
\hline
\end{tabular}

Note: NT, not tested.

1955 to 1968 is chronologically presented in Table 1.

There was an outbreak of acute nephritis in Shōnai district in 1955. It was the first wave of the streptococcal infection recognized in the prefecture since the World War II. A total of 525 cases was reported and the majority of these patients were children of 3 to 14 years of age. Results of the bacteriological investigation indicated that all of the strains isolated from the children of nephritis and of pharyngitis and from healthy contacts were $\beta$-hemolytic streptococci of group C. The prefecture is known to be a famous breeding area of the horse, 
during the last 15 years in Yamagata Prefecture

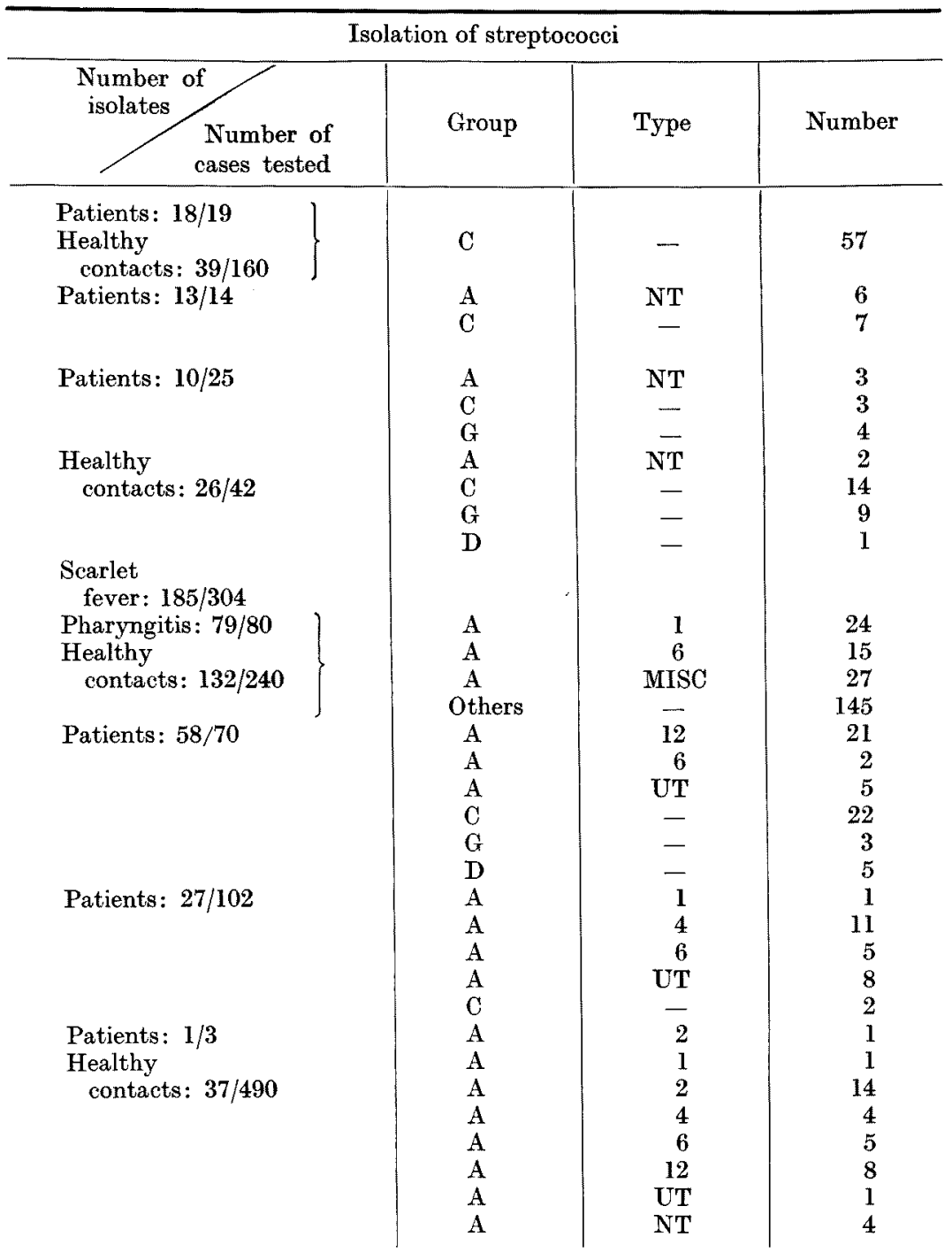

MISC, miscellaneous. UT, untypable.

but no particular effort was made to correlate these isolates with enzootic infection among the horses.

In 1956, a localized outbreak of acute nephritis was found in Tendō City of Murayama county. This area is also famous for breeding horses. Nineteen children of the elementary school were affected. Seven out of 14 tested the throat specimens gave group $\mathrm{C}$ streptococci and 6 out of the rest gave group A streptococci.

In 1957, an outbreak of acute nephritis occurred again in the Shōnai district. 


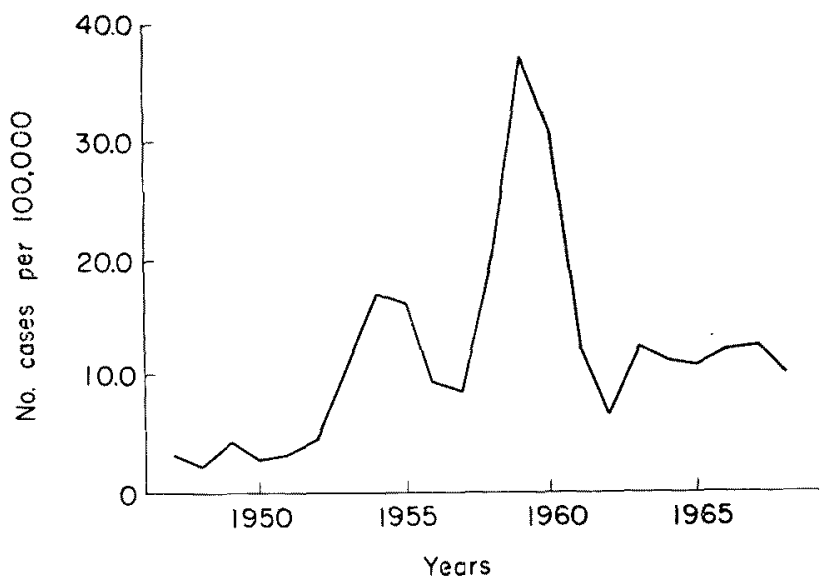

Fig. 2. Incidence of reported cases of scarlet fever in Yamagata Prefecture.

The diagnosed cases reached to 109 and the majority of the patients were younger children as in 1955. From the throat of these patients, 3 group A, 3 group C and 4 group $G$ streptococci were isolated. From the throat culture of the contacts, 14 strains of group C, 2 of group A, 9 of group G and 1 of group D streptococci were isolated. In this year, relatively high incidence of the group $\mathrm{C}$ isolation was noticed from the patients with acute nephritis throughout the prefecture. The above 3 epidemics of acute nephritis are characterized by the outbreaks from summer to autumn.

During the autumn season of 1959 , an outbreak of scarlet fever took place in Shōnai district. From 291 patients of scarlet fever 185 out of 304 throat cultures gave the positive isolation of $\beta$-hemolytic streptococci, but the further examination of these strains was interrupted by an accident. Among 211 strains, which were isolated from the healthy contacts and the contacts with pharyngitis, 66 strains of group A were typed; 24 strains of type 1, 15 of type 6 and 27 of other types were identified, and the causative agents for this outbreak were assumed to be both types 1 and 6. Incidence of scarlet fever based upon reports ${ }^{6}$ from the hospitals throughout the prefecture reached to the highest in this year, that is 37.3 per 100,000 population (Fig. 2).

From 1957 to 1960 , many cases of acute nephritis were reported in both Murayama and Okitama counties. The main isolate was type 12, as was the case with the whole Japan for these years.

From 1964 to 1966, the bacteriological examinations of the sporadic cases of acute pharyngitis in Yamagata City, the capital of the prefecture, yielded 27 strains of $\beta$-hemolytic streptococci from 102 cases. They were types 1,4 and 6 as illustrated in Table 1. Again group C streptococci were isolated, although the number was restricted to 2 .

In 1968, there was a small outbreak of acute nephritis in Yamagata City. 
TABLE 2. Monthly incidence of pharyngitis and tonsillitis associated with group $A$ hemolytic streptococcus

\begin{tabular}{cl|c|c|c}
\hline Month & $\begin{array}{c}\text { Number of } \\
\text { case studied }\end{array}$ & $\begin{array}{c}\text { Number of posi- } \\
\text { tive isolation }\end{array}$ & $\begin{array}{c}\text { Percentage of } \\
\text { positive isolation }\end{array}$ \\
\hline \multirow{2}{*}{1968} & June & 24 & 2 & 8.3 \\
& July & 62 & 14 & 22.6 \\
August & 18 & 5 & 22.8 \\
September & 25 & 9 & 36.0 \\
October & 21 & 10 & 47.6 \\
November & 27 & 6 & 22.2 \\
December & 33 & 12 & 36.4 \\
January & 37 & 8 & 21.6 \\
February & 40 & 5 & 12.5 \\
March & 25 & 1 & 32.0 \\
April & 17 & 3 & 5.9 \\
May & 18 & 6 & 16.7 \\
June & 41 & 89 & 14.6 \\
\hline
\end{tabular}

TABLE 3. Age and sex distribution of pharyngitis and tonsillitis

\begin{tabular}{c|c|c|c}
\hline $\begin{array}{c}\text { Age } \\
\text { (year) }\end{array}$ & Male & Female & Subtotal \\
\hline $0-2$ & 30 & 17 & 47 \\
$3-5$ & 30 & 18 & 48 \\
$6-8$ & 32 & 21 & 53 \\
$9-11$ & 20 & 17 & 37 \\
$12-14$ & 15 & 15 & 30 \\
$15-17$ & 24 & 10 & 34 \\
$18-23$ & 14 & 7 & 21 \\
$24-29$ & 13 & 7 & 20 \\
$30-35$ & 22 & 13 & 35 \\
$36-41$ & 20 & 14 & 29 \\
$42<$ & 20 & 148 & 34 \\
\hline Total & 240 & & 388 \\
\hline
\end{tabular}

From the patients and the healthy contacts, an isolation study was carried out, and type 2 was found to be predominant.

\section{2) One year study in a hospital of rural town}

Second part of this work was confined to the correlation of the clinical pictures with the type of isolates in a hospital of a town which locates in Murayama county. As shown in Table 2, 388 cases in total were studied during one year from June 1968 to June 1969.

I. Monthly incidence of acute pharyngitis and tonsillitis (Table 2)

In monthly distribution study of acute pharyngitis and tonsillitis, the highest incidence was found in July 1968. From January to February 1969, there was the second but minor incidence of outbreak. However, the rate of positive isolation varied monthly from 5.9 to 47.6 per cent. Patients in October 1968 presented the 

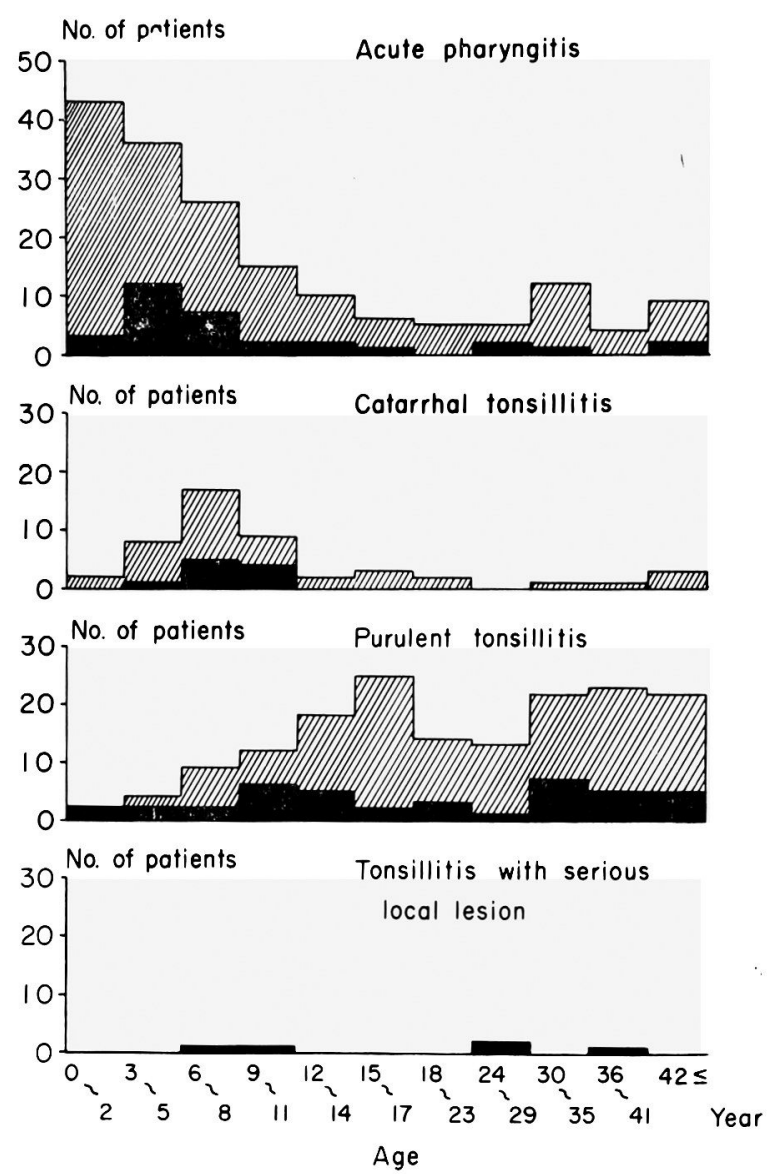

Fig. 3. Streptococcus-isolation from four clinical groups and age distribution.

Solid bars represent the cases from which group A streptococci were isolated.

highest rate of the isolation.

II. Distribution of patients by sex and age (Table 3)

The male patients were 240 and female, 148. The highest incidence was found among the patients of 6 to 8 years of age, followed by the ones of lower age. The fact was shown that there were many adult patients who were assumed to have been infected from their children. The number of male patients overcame that of female patients in every age group.

III. Clinical findings in relation to the isolated organism

The majority of the patients complained of pharyngeal pain and fever of about $38^{\circ} \mathrm{C}$. Only one case of pharyngitis, who was 5 years of age, was accompanied by light scarlatina-like eruption. Acute nephritis did not follow as far as the laboratory examinations were concerned.

Among "acute pharyngitis" cases, the younger children showed a higher 
TABLE 4. Clinical classification and associated streptococcus

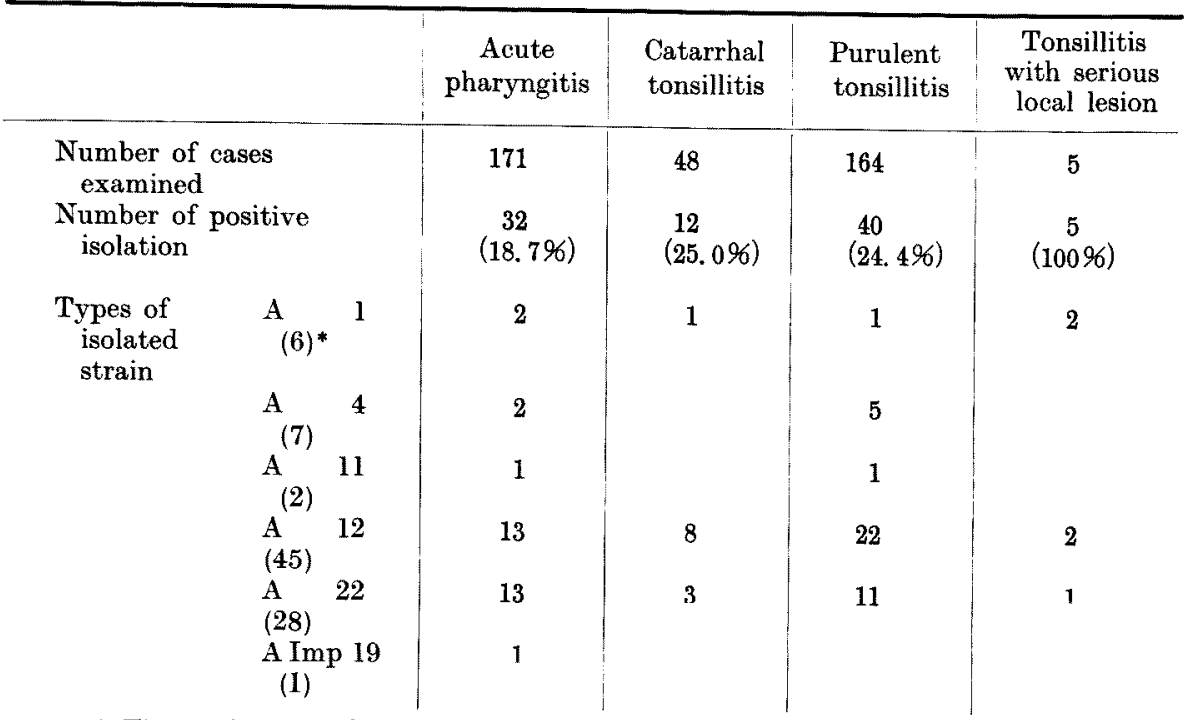

* Figures in parentheses represent total number of each type.

isolation rate of streptococcus. Most characteristically, about one half of the patients with this diagnosis was the children under 5 years of age (Fig. 3). As shown in Table 4, 32 out of such 171 cases revealed positive isolation of streptococci $(18.7 \%$ ). Among 32 strains, A12 and A22 were predominant.

Forty eight patients were classified as "catarrhal tonsillitis", and 12 out of them yielded group A streptococci (25\%). The majority of these strains were Al2 and the rest included $3 \mathrm{~A} 22$ and one Al. Age distribution of this group was distinct and characteristic as shown in Fig. 3. Firstly, infants under 2 years of age were rather rare. Secondly, the highest incidence existed among the children of 6 to 8 years of age. The incidence diminished when they reached to 12 years old.

In the case of "purulent tonsillitis", the age distribution rather shifted toward older groups. Infantile cases were rare and the highest incidence was found in 15 to 17 years of age. Relatively high incidence was found in the age group of over 30 years (67 cases) as illustrated in Fig. 3. From 40 out of 164 cases (24.4 percent) in this category, 40 strains of streptococci were isolated and they were classified as follows; 22 of A12, 11 of A22, 5 of A4, 1 of A1 and A11 (Table 4).

Five cases of "tonsillitis with serious local lesion" were all demonstrated a positive isolation of streptococcus. Five strains from these cases were identified as follows; 2 of A1, 2 of A12 and 1 of A22. These cases were 7, 11, 24, 29, and 41 years of age, respectively.

IV. Seasonal distribution of patients with different clinical features

A seasonal distribution of all streptococcal infections is outlined in the preceding chapters. However, when the clinical features were taken into account, a 

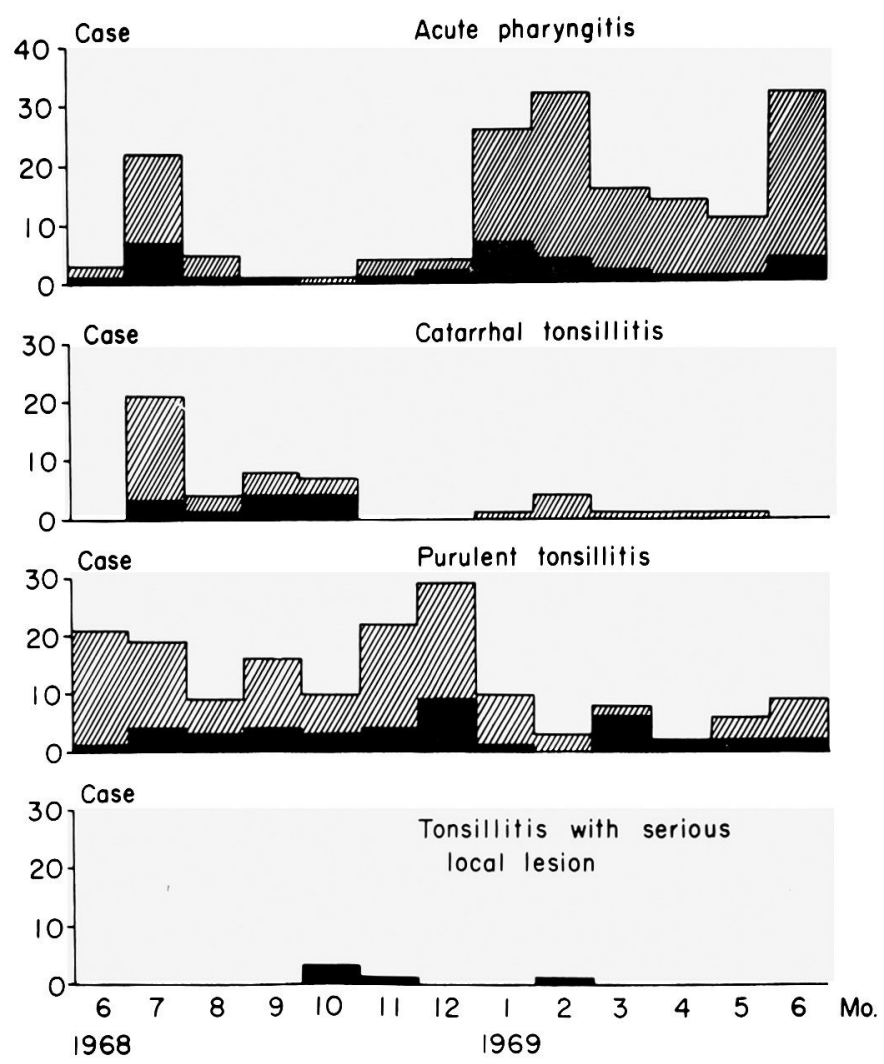

Fig. 4. Seasonal distribution of clinically classified cases.

Solid bars represent the cases from which group A streptococci were isolated.

seasonal distribution was quite different each other among the four clinical groups (Fig. 4). In the figure, the isolation positive cases were illustrated as solid bars.

In the case of acute pharyngitis, two outbreaks were found, i.e., a minor outbreak in midsummer 1968 and a major one in winter 1968 to early spring 1969.

The incidence of catarrhal tonsillitis had somewhat different pattern of seasonal variation from the one obtained with acute pharyngitis. The major outbreak started in midsummer and lasted till October 1968. Minimal incidence was seen from January to May 1969.

Purulent tonsillitis cases were commonly found during the period of the study, but the decreasing tendency was found in 1969 .

The cases of tonsillitis with serious local lesion was only 5. They were found in the autumn and winter season.

V. Monthly distribution of each type of group A streptococci (Fig. 5)

Among 89 strains, type 12 was predominant. Monthly distribution of the type 12 indicated the high incidence in July to October 1968, and from December 1968 to January 1969. Almost the same distribution pattern as type 12 was 

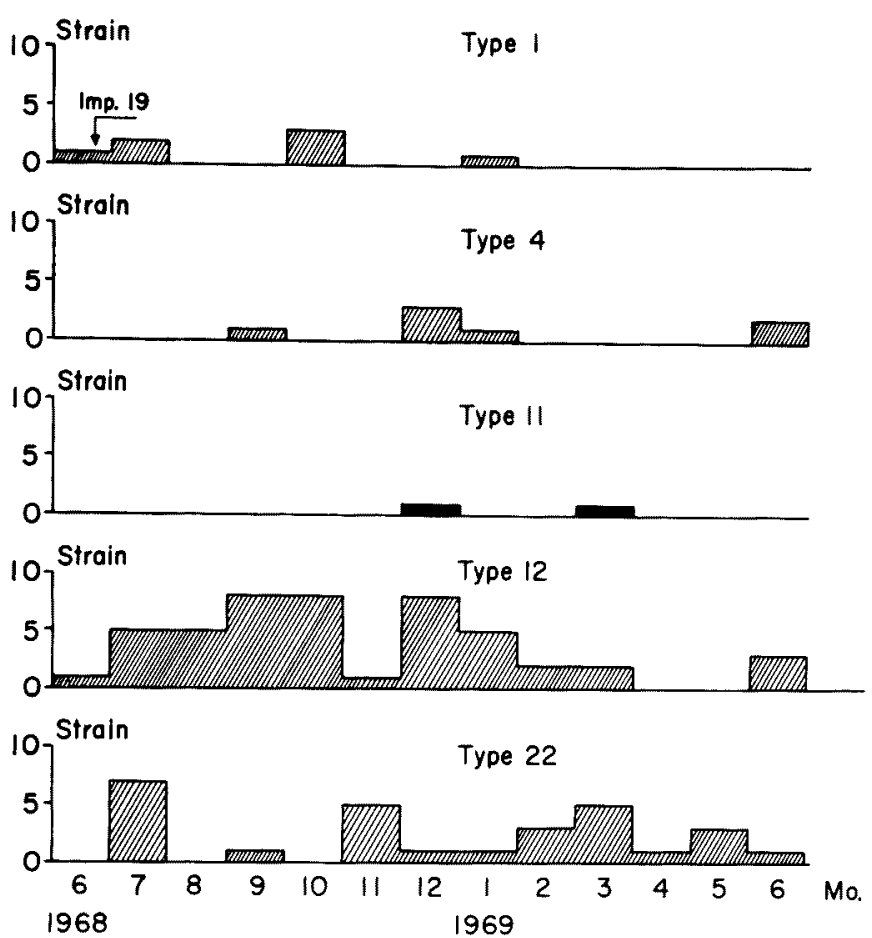

Fig. 5. Seasonal distribution of group A streptococci isolated from pharyngitis.

obtained with type 22. As for minor incidence, such as types 1,4 and 11, the seasonal variation was obscure.

\section{Discussion}

\section{Group C streptococcus and epidemic nephritis}

After the World War II, a big outbreak of acute nephritis was first noticed in Shōnai county (Fig. 1) in 1955. All of the strains from children and healthy contacts were $\beta$-hemolytic streptococci of group C. In many other districts of Japan, the outbreaks of acute nephritis were observed in the same year, ${ }^{7}$ and types 4,6 and 12 of group A streptococci were predominant. Therefore, the outbreak in Yamagata Prefecture should be considered to be an exceptional case. Group C streptococcus has been generally regarded $d^{1,2}$ as responsible only for benign cases of the upper respiratory tract infection except for one case of severe endocarditis. ${ }^{8}$

In Japan, when Nakazawa was dealing with the nephritogenic strains ${ }^{9}$ from 1956 to 1958,34 out of 37 strains from 55 nephritic children were group $A$, and only one strain was group C. ${ }^{10}$ Twenty out of 31 strains from 81 nephritic adults were group A, except for one group $C$ strain. In the survey of Misuno et al. ${ }^{11}$ from 1956 to 1964 , only 1 out of 140 acute nephritis was accompanied by group C streptococcus. In Miyake's study on an outbreak of epidemic nephritis of the primary 
school in $1964,{ }^{12}$ none of the 50 strains isolated from patients belonged to group C, but only 7 out of 264 strains recovered from the contacts were group C. All of these investigations indicate that the incidence of group $\mathrm{C}$ streptococcus infection among the human is very rare.

In 1956, a localized outbreak of the disease was found in Tendō City. Nineteen children of a primary school were affected and examined. Seven out of 14 throat cultures gave group $\mathrm{C}$, and 6 out of the rest gave group $\mathrm{A}$ streptococci.

In 1957, epidemic nephritis again occurred in Shonai district. The number of clinically diagnosed cases was 109 , the majority of which was the same age as the former epidemic. From the throat of these patients, 3 of group A, 3 of group $\mathrm{C}$ and 4 of group $\mathrm{G}$ streptococci were detected. From the contacts, overwhelming 14 strains of group C, 2 of group A and 10 of other groups were detected. Also in other parts of the prefecture, a relatively frequent isolation of group C streptococcus was announced. ${ }^{6}$ Within following 4 years, throat culture of acute nephritis from the inland part of Yamagata Prefecture (Murayama and Okitama counties in Fig. 1) yielded $58 \beta$-hemolytic streptococci including 22 strains of group $\mathrm{C}$ and 28 of group A.

In summary, the outbreaks of acute nephritis of type $\mathrm{C}$ streptococci were found in Shōnai district from 1955 to 1957. Since then, the endemy spraad to the inland part of the prefecture, lasted for 5 years, and was replaced by group $A$ streptococci.

\section{Type prevalence among group $A$ streptococci}

In the fall of 1959, an outbreak of scarlet fever took place in Shōnai district. More than half of the 304 throat cultures of the patients produced $\beta$-hemolytic streptococci, although grouping and typing could not be made. However, from healthy contacts and pharyngitis cases around the patients, 24 strains of type 1 and 15 of type 6 and 27 of other group A streptococci were isolated, and the causative agent of this outbreak was supposed to be both types 1 and 6 . According to Nakajima et al. ${ }^{13}$ gradual decline of the incidence of scarlet fever was noticed since 1957 throughout Japan. However, the nation wide outbreak due to type 6 was noticed in 1962, i.e., the lowest incidence rate of 6.6 per 100,000 in 1961 turned to be 16.7 in 1963. In Yamagata Prefecture, as mentioned above, the remarkably high incidence of scarlet fever was found rather earlier in 1959. The peak incidence in 1959 was the highest with the rate of 37.3 per 100,000 (Fig. 2).

Prior to the increase of scarlet fever in 1962, types 3, 4,6 and 12 of group A were isolated from endemic cases in Tokyo in 1956, and types 1, 3, 4,6 and 12 for following three years ${ }^{14}$ (Table 5). Thus the predominance of type 6 in Tokyo before and after 1962 was evident. The type 6 was also predominant in a big outbreak of scarlet fever in Osaka from 1962 to $1963,{ }^{13}$ but it was replaced by type 4 in 1964 . Later in 1966, type 6 was again predominant in Osaka. ${ }^{15}$ However, in Akita Prefecture, north of Yamagata, type 1 was predominant in $1964^{16}$ and was replaced by type 6 in $1965 .{ }^{17}$ In the endemy of 1967, type 6 was again predominant in 
TABLE 5. Type of group A streptococci isolated in Japan during 1937-1968

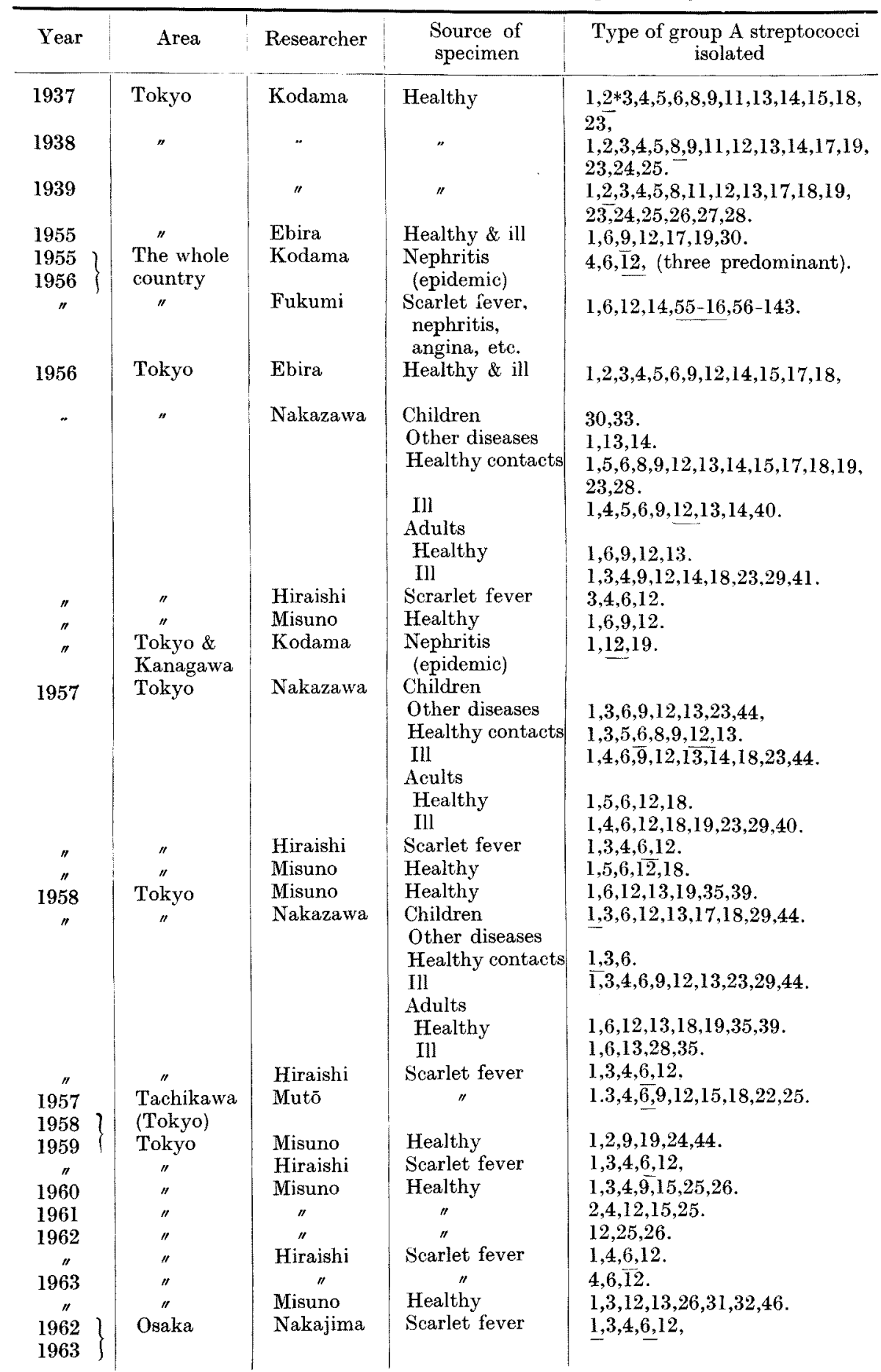


TABle 5. Continued

\begin{tabular}{c|l|l|l|l}
\hline Year & Area & Researcher & \multicolumn{1}{|c}{$\begin{array}{c}\text { Source } \\
\text { of specimen }\end{array}$} & \multicolumn{1}{|c}{ Type of group A streptococei } \\
isolated
\end{tabular}

* Figures with underlines were the most frequently isolated strains in the survey.

Akita Prefecture. ${ }^{18}$ In 1966, Miyamoto et al..$^{19}$ reported that both types 4 and 6 were predominant in Kanagawa Prefecture, west of Tokyo. In Tokyo ${ }^{20}$ and Niigata, ${ }^{21}$ type 6 was predominant in the same year. However, Shimizu et al. ${ }^{22}$ reported an outbreak of scarlet fever in Tokyo due to type 14 from 1966 to 1967. These literal considerations tabulated in Table 5 reveal that type 6 is the real and most common causative agent of prevalent outbreaks of scarlet fever in Japan except for a few instances, such as types $4,{ }^{23-26} 14^{22}$ and $22 .{ }^{27}$

As concerns the isolates from the infection other than those mentioned above, 27 strains of $\beta$-hemolytic streptococci were isolated out of 102 cases of acute pharyngitis in Yamagata Prefecture (Table 1). These strains included 1 type 1, 11 type 4,5 type 6 and 8 untypable strains of group A. From 1968 to 1969 , however, the main current type was 12, followed by type 22 .

All of the types of group A streptococci so far isolated in Japan from 1937 to 1967 are listed in Table 5. Before the World War II, group A streptococci isolated from the healthy subjects in Tokyo were classified by Kodama et al. and these details were described by Nakazawa. ${ }^{28}$ Among the types identified, types 2, 4 and 8 were predominant. After the war in 1955 and 1956 in Tokyo, Ebira and 
Kobayashi ${ }^{99}$ classified 1644 strains into 15 types. In this study, types 6 and 9 were predominant. As described above, a country-wide outbreak of acute nephritis occurred in Japan in 1955.10 Strains isolated during this period from various sources were identified by Fukumi and Kusama ${ }^{30}$ as types $1,6,12,14,55-16,56-143$ and untypable strains. The most prevalent type was 55-16, which is closely correlated to type 4, followed by types 6 and 12. But in the nephritis group, type 12 was predominant. $^{10}$ At the same time, Kodama et al. isolated types 1, 12 and 19 from acute nephritis patients in Tokyo and Kanagawa Prefecture. ${ }^{31}$ Here also type 12 was predominant. These results sustain the Rammelkamp's hypothesis of specific nephritogenicity of type 12, together with types 4, 25 and 45 . In Japan, type 6 should be added to those as nephritogenic strain. ${ }^{1}$

In the author's chronological study, types 4,6 and 12 were regarded as nephritogenic strains, so far as group A strains were concerned. However, in the survery from 1968 to 1969,45 out of 388 cases of acute pharyngitis and tonsillitis produced type 12 in their throats, but none of them developed signs or symptoms of acute nephritis, whereas one patient among 3 cases of nephritic children and 14 contacts produced type 2 . Accordingly, type 2 might be added as a new nephritogenic strain.

\section{Epidemiology of streptococcal infections}

An absence of immunity and a close contact are regarded as two principal factors determining the spread of streptococcal infection. Holmes et al. ${ }^{\mathbf{3 2}}$ stated that the continued spread of the infection in a cottage was commonly due to the arrival of the new children and was almost always associated with the presence of nasal carriers of streptococci. She stated that a new incidence of the infection was derived apparently from a new importation of the particular type. Kuttner and Krumwiede ${ }^{33}$ found that different types were present every year among the children of Irvington House for Rheumatic Fever Patients. They are always in a carrierstate of a particular strain. However, when an outbreak of streptococcal infection occurred, this was caused by a new type, and the strain would later become as one of the carrier strains. In explaining these observation, Dunlap and Harvey ${ }^{5}$ described that type-specific antibodies were absent from the sera of actually ill persons. When a convalescent carrier state was resulted, a gradual rise in antibody titer could be found for two to six months. These high titers can persist as long as six years.

Looking through the Table 5, the persistence of the particular types in the big cities like Tokyo and Osaka results in the second outbreak probably because of the importation of a new susceptible population. In rural population, however, an occasion of the infection is assumed to be smaller than in the urban population, because the low density of rural population may interrupt the vast spread of infection. Nevertheless, the current types in a particular year become prevailed between the urban and the rural population. 


\section{Pharyngitis and tonsillitis}

In the latter part of the studies attempting to correlate the clinical manifestations with the types of straptococci isolated from the throat, the author could not detect a strain of group $\mathrm{C}$ or $\mathrm{G}$ from 388 acute pharyngitis patient, whereas Hill et $a l .^{34}$ recently reported an epidemic of acute pharyngitis in a college by group $\mathrm{G}$ streptococcus.

As far as clinical manifestation of the streptococcus infections are concerned, the severe streptococcal infections such as scarlet fever and nephritis could not be found in this particular year study. This is in agreement with the results obtained by others. ${ }^{1}$ This can be explained by the genetic variation ${ }^{35}$ or the elimination of lysogenic phages. ${ }^{36}$

However, acute pharyngitis or catarrhal tonsillitis due to streptococcal infection is still persisting. The former was the manifestation of the children under 10 years old and the latter was that of rather older school children. Low isolation rate of streptococcus in the former group awaits further detailed bacteriological and virological studies.

In the present study, relatively high incidence of streptococcal angina in adults over 30 years old was indicated. Epidemiological analyses revealed that these adult patients were the father or mother of the school children, and they might be infected from their own children at home.

\section{References}

1) Miyamoto, Y. Discussions in W.H.O. Expert Advisory Committee on coccal infections. Media Circle (Jap.), 1968, 13, 313-325.

2) MoCarty, M. The hemolytic Streptococci. Bacterial and Mycotic Infections of Man, 4th Ed., edited by R.J. Dubos \& J.G. Hirsh, Philadelphia, J.B. Lippincott Company, 1965, pp. 360-376.

3) Miyamoto, Y. First international streptococcus type distribution survey. Media Circle (Jap.), 1967, 12, 363-374.

4) Yanagishita, T. Recent problems on scarlet fever. J. Jap. Ass. infect. Dis. (Jap.), 1957, 31, 473-482.

5) Dunlap, M.B. \& Harvey, H.S. The carrier state and type-specific immunity in streptococcal disease. Amer. J. Dis. Child., 1967, 114, 229-243.

6) Kikuchi, H. Outbreaks of various infectious diseases. Ann. Report of Department of Public Health Service of Yamagata Prefectual Government (Jap.), 1967.

7) Kodama, T., Miyamoto, Y., Kotake, I. \& Ochiai, S. Epidemic nephritis in Japan. Yokohama med. Bull., 1958, 9, 105-118.

8) Sanders, V. Bacterial endocarditis due to a group C beta hemolytic streptococcus. Ann. intern. Med., 1963, 58, 858-861.

9) Rammelkamp, C.H., Jr. \& Weaver, R.S. Acute glomerulonephritis. The significance of the variance of the disease. $J$. clin. Invest., 1953, 32, 345-358.

10) Nakazawa, H. An epidemiological study of streptococcus hemolyticus. J. Jap. Ass. infect. Dis. (Jap.), 1960, 34, 63-97.

11) Misuno, K., Miwa, T. \& Yokota, M. An epidemiological study of streptococeus hemolyticus. J. Jap. Ass. infect. Dis. (Jap.), 1967, 41, 175-182.

12) Miyake, J. Study on the epidemic nephritis. Acta Paed. Jap., 1967, 70, 740-748.

13) Nakajima, K., Hirozumi, S., Akao, M. \& Nakamura, K. Recent prevalence of scarlet fever in Osaka district. J. Jap. Ass. infect. Dis. (Jap.), 1963, 38, 181-192. 
14) Hiraishi, K. Group A streptococci isolated from scarlet fever. Jap. med. J. (Jap.), 1963, No. 2067, 7-11.

15) Nakajima, K., Nakamura, K., Tanigaki, T. \& Yasui, H. Types and sensitivity of streptococcus from scarlet fever during the last five years. J. Jap. Ass. infect. Dis., (Jap.), 1967, 41, 318-319.

16) Kyogoku, H., Watanabe. J. \& Abe, M. Types and sensitivity of streptococcus from scarlet fever. Jap. J. med. Technol., (Jap), 1965, 14, 359-360.

17) Watanabe, J. \& Yamada, I. Scarlet fever in 1965. J. Jap. Ass. infect. Dis. (Jap.), $1966,40,257$.

18) Suto, T. Prophylaxis of scarlet fever by antibiotics. Ann. Report of the Public Health Institute of Akita Prefecture, 1967, 12, 98-104.

19) Miyamoto, Y., Kodama, T., Akiyama, S., Kato, T., Ichinohe, H., Takizawa, K., Matsushima, S., Obara, Y., Nagashima, K. \& Yamai, S. A type distribution survey of group-A hemolytic streptococci by agglutination method. J. Jap. Ass. infect. Dis. (Jap.), 1966, 40, 334-336.

20) Tanji, S., Hirayama, A. \& Kimura, H. Scarlet fever in a hospital. J. Jap. Ass. infect. Dis. (Jap.), 1966, 40, 261.

21) Homma, H. \& Hasegawa, T. Streptococcal infections. Ann. Report of the Public Health Institute of Niigata Prefecture, 1967-1968, pp. 15-16.

22) Shimizu, N., Yanagishita, T. \& Misuno, K. Scarlet fever in a class of a primary school. J. Jap. Ass. infect. Dis. (Jap.), 1968, 41, 397.

23) Iimura, T. Types of streptococcus from scarlet fever. J. Jap. Ass. infect. Dis. (Jap.), 1965, 39, 352.

24) Miyamoto, Y., Kodama, T., Akiyama, S., Kato, T., Ichinohe, H., Takizawa, K., Matsushima, S., Obara, Y., Nagashima, K., Yamai, S., Nakamura, B., Kimura, M., Sunaoshi, H., Yamagami, S., Nakajima, K., Nakamura, K., Tanigaki, T., Yasui, H., Nakamura, M., Iida, H., Karashimada, T. \& Matsuda, S. Current strains of type A streptococci. J. Jap. Ass. infect. Dis. (Jap.), 1966, 40, 32-38.

25) Iimura, T. Scarlet fever in recent days. Media Circle, (Jap.), 1968, 13, 95-111.

26) Misuno, K., Miwa, T., Kobayashi, K., Shimizu, N. \& Yokota, M. Types of streptococci in 1964. J. Jap. Ass. infect. Dis. (Jap.), 1965, 39, 135-137.

27) Misuno, K., Shimizu, N. \& Yokota, M. Types of streptococcus isolated in $1965 . J$. Jap. Ass. infect. Dis. (Jap.), 1967, 41, 319.

28) Nakazawa, H. An epidemiological study of streptococcus hemolyticus. J. Jap. Ass. infect. Dis. (Jap.), 1960, 34, 63-97.

29) Ebira, Y. \& Kobayashi, K. Groups and types of streptococcus from scarlet fever. J. Jap. Ass. infect. Dis. (Jap.), 1957, 31, 346-356.

30) Fukumi, H. \& Kusama, H. Recent types of streptococous group A in Japan. $J$. Jap. Ass. infect. Dis. (Jap.), 1958, 31, 626-627.

31) Kodama, T. Streptococcal infection. Jap. J. Bacteriol. (Jap.), 1957, $12,511$.

32) Holmes, M.C., Williams, R.E.O., Bloom, C.V., Hirch, A., Lermit, A. \& Woods, E. Streptococcal infections among children in a residential home. 4. Outbreaks of infection. J. Hyg. Camb., 1958, 56, 211-237.

33) Kuttner, A.G. \& Krumwiede, E. Observations on the epidemiology of streptococcal pharyngitis and the relation of streptococcal carriers to the occurrence of outbreaks. J. clin. Invest., 1944, 23, 139-150.

34) Hill, H.R., Caldwell, G.G., Wilson, E., Hager, D. \& Zimmerman, R.A. Epidemic of pharyngitis due to streptococoi of Lancefield group G. Lancet, 1969, 2, 371-374.

35) Rothbard, S. \& Watson, R.F. Variation occurring in group A streptococci during human infection. J. exp. Med., 1948, 87, 521-533.

36) Zabriskie, J.B. The role of temperate bacteriophage in the production of erythrogenic toxin by group A streptococci. J. exp. Med., 1964, 119, 761-780. 